ISSN: 2302-8556

E-Jurnal Akuntansi Universitas Udayana

Vol.23.1. April (2018): 677-704

DOI: https://doi.org/10.24843/EJA.2018.v23.i01.p26

\title{
Pengaruh Agresivitas Pajak Pada Corporate Social Responsibility dengan Ukuran Perusahaan Sebagai Pemoderasi
}

\author{
Ida Ayu Intan Suryadewi ${ }^{1}$ \\ Ni Ketut Rasmini ${ }^{2}$ \\ ${ }^{1}$ Fakultas Ekonomi dan Bisnis Universitas Udayana (Unud), Bali - Indonesia \\ email: idaayuintan@gmail.com / Telp: 081338488481 \\ ${ }^{2}$ Fakultas Ekonomi dan Bisnis Universitas Udayana (Unud), Bali - Indonesia
}

\begin{abstract}
ABSTRAK
Corporate Social Responsibility (CSR) merupakan suatu komitmen bisnis untuk memberikan kontribusi bagi pembangunan ekonomi berkelanjutan yang dilaksanakan dengan cara menjalin suatu kerja sama dengan para karyawan, perwakilan perusahaan serta masyarakat umum. CSR suatu perusahaan dapat dipengaruhi oleh agresivitas pajak dan ukuran perusahaan. Tujuan penelitian ini adalah untuk mengetahui pengaruh agresivitas pajakpada corporate social responsibility serta untuk mengetahui bahwa ukuran perusahaandapat memoderasi pengaruh agresivitas pajak pada corporate social responsibility. Penelitian ini dilakukan pada perusahaan sektor pertambangan yang terdaftar di Bursa Efek Indoneisa (BEI) tahun 2014-2016. Penentuan sampel pada penelitian ini menggunakan metode purposive sampling. Teknik analisis data yang digunakan yaituModerated Regression Analysis (MRA). Berdasarkan hasil penelitian diketahui bahwa agresivitas pajak secara positif berpengaruh pada corporate social responsibility. Penelitian ini juga menunjukkan bahwa ukuran perusahaanmampu memoderasi pengaruh agresivitas pajak pada corporate social responsibility.

Kata Kunci: Corporate Social Responsibility, Agresivitas Pajak, Ukuran Perusahaan
\end{abstract}

\begin{abstract}
Corporate Social Responsibility (CSR) is a business commitment to contribute to sustainable economic development that is implemented by establishing a partnership with employees, corporate representatives and the general public. A company's CSR can be affected by tax aggressiveness and firm size. The purpose of this study is to determine the effect of tax aggressiveness on corporate social responsibility and to determine whether firm size can moderate the effect of tax aggressiveness on corporate social responsibility.This research was conducted on mining companies listed on the Stock Exchange Indoneisa (BEI) in 20142016. The sampling method was purposive sampling. Data analysis technique used is Moderated Regression Analysis (MRA). Based on the results of research, it is known that tax aggressiveness negatively affect corporate social responsibility. This research also shows that firm size is able to moderate the influence of tax aggressiveness on corporate social responsibility.
\end{abstract}

Keywords: Corporate Social Responsibility, Tax Aggressiveness, Firm Size 
Ida Ayu Intan Suryadewi dan Ni Ketut Rasmini.Pengaruh...

\section{PENDAHULUAN}

Kehadiran perusahaan sebagai bagian dari masyarakat diharapkan dapat memberikan manfaat bagi masyarakat sekitar. Namun, kenyataannya semakin berkembangnya suatu perusahaan akan berdampak pada kesenjangan sosial dan kerusakan lingkungan yang semakin tinggi, hal tersebut diakibatkan oleh aktivitas operasi perusahaan terhadap sumber daya yang tidak terkendali dengan tujuan untuk meningkatkan laba perusahaan. Dampak dari aktivitas operasi perusahaan juga dirasakan oleh masyarakat dan lingkungan sekitar perusahaan. Oleh karena itu, perusahaan saat ini diharapkan tidak hanya memperhatikan aspek keuangan perusahaan semata (single bottom line) melainkan meliputi aspek keuangan, aspek sosial dan aspek lingkungan (triple bottom line). Tidak dapat dipungkiri bahwa suatu respon positif dari masyarakat dibutuhkan oleh perusahaan demi mencapai suksesnya suatu entitas melalui apa yang dilakukan oleh perusahaan kepada para stakeholders, termasuk masyarakat dan lingkungan sekitar(Kamil dan Antonius, 2012). Tanggungjawab suatu perusahaan terhadap lingkungan dan masyarakat, baik yang secara langsung terkait maupun tidak dengan perusahaan dikenal dengan istilah Corporate Social Responsibility (CSR). Lanis dan Richardson (2012) menyatakan CSR merupakan salah satu faktor utama dalam menentukan keberlanjutan hidup perusahaan. Pengimplementasian program-program CSR diharapkan dapat memberikan dampak positif bagi lingkungan yang nantinya dapat dinikmati oleh suatu perusahaan dan juga oleh seluruh pemangku kepentingan. Perkembangan CSR di Indonesia terkait dengan semakin banyaknya masalah lingkungan yang diakibatkan oleh aktivitas operasional perusahaan. 
Sejalan dengan hal tersebut, pengungkapan Corporate Social Responsiility merupakan suatu kewajiban bagi setiap perusahaan yang diatur oleh pemerintah dalam Undang-Undang RI No. 40 tahun 2007 pasal 74 tentang “Tanggung Jawab Sosial dan Lingkungan". Undang-undang tersebut mengamanatkan bahwa "Perseroan yang menjalankan kegiatan usahanya di bidang dan/atau berkaitan dengan sumber daya alam wajib melaksanakan Tanggung Jawab Sosial dan Lingkungan” (Utari dan Rohman, 2015). Pada kenyataannya, saat ini masih ada perusahaan yang tidak mengikuti dan mantaati peraturan tersebut.

PT Freeport Indonesia merupakan salah satu contoh perusahaan yang dalam kegiatan operasinya tidak memperhatikan masalah sosial dan lingkungan sekitar. PT Freeport Indonesia yang merupakan perusahaan penghasil emas terbesar melalui tambang Grasberg memulai operasinya sejak tahun 1967 dengan mengekploitasi kekayaan sumber daya alam bumi Papua dan tidak henti-hentinya dalam melakukan aktivitas menambang emas, perak dan tembaga. Kehadiran PT Freeport di Papua selama hampir setengah abad terus memunculkan berbagai macam masalah, mulai dari setoran ke negara yang dinilai masih sangat rendah. Selain hal tersebut, Freeport Indonesia juga melakukan pelanggaran dalam etika bisnis dengan membayar upah kepada para pekerja secara tidak layak serta melanggar Undang-Undang 11/1967 tentang Ketentuan-Ketentuan Pokok Pertambangan yang sudah diubah menjadi Undang-Undang Nomor 4/2009 tentang Minerba. Pemilihan perusahaan sektor pertambangan yang terdaftar di Bursa Efek Indonesia (BEI) sebagai lokasi penelitian karena berdasarkan Undang - undang No.40 Tahun 2007, kususnya Pasal 74 tentang Perseroan Terbatas 
Ida Ayu Intan Suryadewi dan Ni Ketut Rasmini.Pengaruh...

menyatakan bahwa perseroan yang menjalankan kegiatan usahanya di bidang dan/atau berkaitan dengan sumber daya alam wajib melaksanakan tanggung tawab sosial dan lingkungan. Darwin dalam Karina (2013) berpendapat bahwa perusahaan memiliki satu tujuan dalam mengungkapkan kinerja lingkungan, sosial, dan finansial di dalam laporan tahunan. Menjalin hubungan komunikasi yang baik dan efektif antara perusahaan dengan masyarakat dan stakeholder lainnya tentang bagaimana perusahaan telah menginteraksikan CSR dan lingkungan sosial dalam setiap aspek kegiatan operasinya merupakan tujuan utama dari pengungkapan ini.

Salah satu faktor yang dapat mempengaruhi corporate social responsibility adalah pajak. Pajak secara umum dapat didefinisikan sebagai pungutan yang dilakukan pemerintah berdasarkan atas peraturan perundangundangan dan digunakan untuk pembiayaan negara. Pajak yang dibayarkan oleh perusahaan dihitung dari laba bersih yang diperoleh perusahaan tersebut. Oleh karena itu, bagi suatu perusahaan pajak dianggap sebagai biaya yang dapat mengurangi keuntungan dari perusahaan sehingga dapat memperkecil laba bersih. Kondisi tersebut mengakibatkan banyak perusahaan berusaha untuk mencari suatu cara agar dapat mengurangi biaya pajak yang harus dibayar, sehingga tidak menutup kemungkinan perusahaan akan menjadi agresif dalam perpajakan (Chen et al., 2010). Andhari dan Sukharta (2017) menyatakan pajak memiliki unsur memaksa mengakibatkan banyak perusahaan sebagai wajib pajak berusaha untuk melakukan praktek perlawanan pajak. Perlawanan pajak yang dilakukan oleh perusahaan dapat diwujudkan dalam bentuk agresivitas pajak. Jadi dapat diartikan 
bahwa agresivitas pajak sebagai kegiatan manajemen perusahaan dalam menekan dan meminimalisir beban pajak yang harus dibayar perusahaan (Aryudanto, 2016).

Perusahaan beranggapan bahwa perusahaan memiliki dua beban yaitu beban pajak dan beban CSR (Setiadji, 2010). Hal tersebut menyebabkan banyak perusahaan yang berusaha untuk mencari alternatif lain, salah satunya adalah melakukan agresivitas pajak. Lanis dan Richardson (2013) berpendapat bahwa, masyarakat akan berpandangan negatif terhadap perusahaan yang melakukan tindakan agresivitas pajak karena dianggap telah melakukan suatu kegiatan yang tidak bertanggungjawab secara sosial dan hal tersebut tidak sah. Oleh karena itu, perusahaan yang telah terbukti melakukan agesivitas pajak akan dapat bertindak sesuai dengan teori legitimasi yaitu dengan cara melakukan pengungkapan informasi CSR tambahan (Lanis dan Richardson (2013) dengan tujuan mengubah persepsi masyarakat dan mendapat legitimasi dari masyarakat. Beberapa penelitian tentang pengaruh agresivitas pajak pada corporate social responsibility menunjukkan hasil yang beragam, diantaranya Lanis dan Richardson (2013), serta Laguir et al. (2015) menyatakan agresivitas pajak memiliki pengaruh positif pada corporate social responsibility. Hal ini juga didukung oleh Rini, dkk (2015), Plorensia A.P. dan Hardiningsih (2015) serta Utari dan Rohman (2015). Sedangkan Octaviana dan Rohman (2014) serta Zeng (2012) menyatakan agresivitas pajak berpengaruh negatif terhadap corporate social responsibility.

Berdasarkan ketidakkonsistenan hasil penelitian tersebut, maka peneliti ingin meneliti kembali pengaruh agresivitas pajak pada corporate social 
Ida Ayu Intan Suryadewi dan Ni Ketut Rasmini.Pengaruh...

responsibility dengan menambahkan ukuran perusahaan sebagai variabel moderasi, untuk mengetahui apakah ada variabel lain yang dapat mempengaruhi agresivitas pajak terhadap corporate social responsibility. Menurut Rodriguez dan Arias (2012) ukuran perusahaan dapat diartikan sebagai suatu skala dimana perusahaan diklasifikasikan besar atau kecil dari berbagai sudut pandang, salah satunya dinilai dari besar kecilnya aset yang dimiliki perusahan. Zulaikha (2014) berpendapat bahwa besar kecilnya perusahaan dapat mempengaruhi pendapatan (profitability), sehingga berpengaruh terhadap pembayaran pajak. Sejalan dengan Haryanto (2015) yang menyatakan ukuran perusahaan berpengaruh positif terhadap pengungkapan corporate social responsibility.

Berdasarkan penjelasan di atas, variabel ukuran perusahaan tersebut diduga dapat mempengaruhi hubungan agresivitas pajak pada corporate social responsibility. Berdasarkan paparan permasalahan diatas, maka peneliti tertarik untuk mengangkat topik penelitian yang berjudul Pengaruh Agresivitas Pajak pada Corporate Social Responsibility dengan Ukuran Perusahaan sebagai Pemoderasi.Rumusan masalah yang dapat diajukan yaitu apakah agresivitas pajak berpengaruh pada pengungkapan corporate social responsibility?, serta apakahukuran perusahaan mempengaruhi hubungan agresivitas pajak pada pengungkapan corporate social responsibility?.

Penelitian ini bertujuan untuk memperluas pegetahuan dan menambah pemahaman tentang pengungkapan corporate social responsibility. Hasil penelitian inidiharapkan dapat menjadi referensi bagi peneliti selanjutnya. 
Penelitian ini juga diharapkan dapat memberikan masukan dan dapat dijadikan pertimbangan dalam mengambil keputusan oleh para pengguna laporan keuangan. Teori legitimasi merupakan teori yang dikembangkan oleh Gray et al. (1996). Menurut Sari (2012), legitimasi merupakan manfaat atau sumber daya potensial bagi perusahaan untuk mempertahankan hidup. Kelangsungan hidup dari suatu perusahaan bergantung pada hubungan antara perusahaan dengan masyarakat dan perusahaan dengan lingkungan yang menjadi lokasi perusahaan tersebut melakukan aktivitasnya. Teori legitimasi menyatakan bahwa organisasi atau perusahaan berusaha menciptakan keselarasan antara nilai-nilai sosial yang melekat pada aktivitasnya dengan norma perilaku yang ada di masyarakat. Legitimasi masyarakat terhadap perusahaan menjadi suatu faktor yang strategis bagi perkembangan perusahaan sehingga legitimasi merupakan hal yang memiliki peranan penting bagi suatu perusahaan. Perusahaan akan terus berlanjut dan mampu bertahan apabila masyarakat merasa bahwa perusahaan beroperasi untuk sistem nilai yang sesuai dengan sistem nilai masyarakat itu sendiri. Teori legitimasi menganjurkan perusahaan untuk meyakinkan bahwa aktivitas perusahaan tersebut dapat diterima oleh kalangan masyarakat.

Agresivitas pajak merupakan hal yang saat ini sangat lazim dilakukan oleh perusahaan-perusahaan besar maupun kecil di seluruh dunia. Hal tersebut sama seperti yang dinyatakan Balakrishnan et al. (2011) bahwa suatu perusahaan terlibat dalam berbagai bentuk perencanaan pajak untuk dapat mengurangi kewajiban pajak yang diperkirakan. Perusahaan yang melakukan agresivitas pajak akan meminimalkan pembayaran pajak perusahaan demi pencapaian 
Ida Ayu Intan Suryadewi dan Ni Ketut Rasmini.Pengaruh...

keuntungannya (Utari dan Rohman, 2015).

Salah satu karakteristik perusahaan yang penting adalah ukuran perusahaan. Ukuran perusahaan merupakan suatu pengukuran yang dikelompokkan berdasarkan besar kecilnya perusahaan dan dapat menggambarkan aktivitas serta pendapatan perusahaan. Semakin besar ukuran perusahaan maka semakin besar usaha yang dilakukan perusahaan untuk menarik perhatian masyarakat (Nugraha dan Meiranto, 2015). Corporate Social Responsibility merupakan suatu komitmen bisnis untuk memberikan kontribusi bagi pembangunan ekonomi berkelanjutan yang dilaksanakan dengan cara menjalin suatu kerja sama dengan para karyawan serta perwakilan perusahaan, komunitas setempat dan masyarakat umum. Tujuan hal tersebut untuk meningkatkan kualitas hidup dengan cara yang bermanfaat bagi kelangsungan bisnis suatu perusahaan maupun untuk pembangunan. Menurut Michael Fontaine (2013) tanggungjawab sosial perusahaan (CSR) dilakukan tidak hanya demi kepentingan pelanggan dan investor, tetapi juga untuk karyawan, pemasok, pemerintah, dan masyarakat luas.

Adapun kerangka konseptual dalam penelitian ini menunjukkan pengaruh antar variabel dalam penelitian. Kerangka konseptual dalam penelitian ini disajikan pada Gambar 1 sebagai berikut.

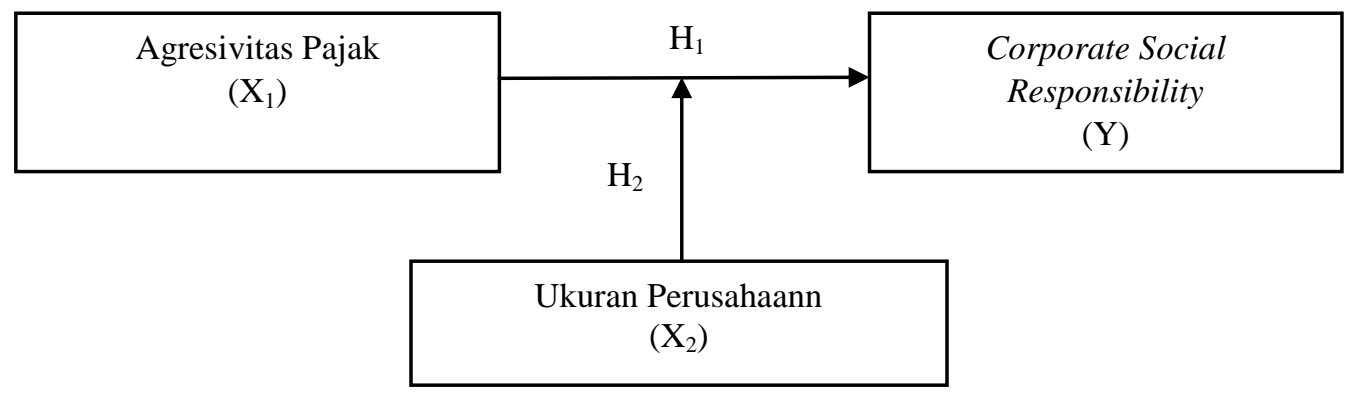

Gambar 1. Kerangka Konseptual 
Tindakan meminimalkan pajak atau disebut agresivitas pajak kerap dilakukan oleh perusahaan-perusahaan besar. Hal tersebut disebabkan karena perusahaan merasa terbebani dengan jumlah pajak yang harus ditanggungnya. Tindakan tersebut pada dasarnya tidak sesuai dengan harapan masyarakat dan memiliki dampak negatif terhadap masyarakat karena mempengaruhi kemampuan pemerintah dalam menyediakan barang publik (Lanis dan Richardson, 2013). Perilaku meminimalkan pajak menyebabkan pajak tidak lagi mampu secara maksimal dalam menyejahterakan masyarakat (Harari, et.al, 2012). Menurut Lanis dan Richardson (2013) pandangan masyarakat mengenai perusahaan yang melakukan tindakan agresivitas dianggap telah membentuk suatu kegiatan yang tidak bertanggung jawab secara sosial dan tidak sah. Tindakan tersebut secara tidak langsung menjadi perhatian publik yang mana bisa mengubah persepsi masyarakat terhadap perusahaan menjadi negatif (Utari dan Rohman, 2015). Penelitian terdahulu yang dilakukan oleh Lanis dan Richardson (2013), serta Laguir et al. (2015) menyatakan agresivitas pajak memiliki pengaruh positif pada corporate social responsibility. Hal ini juga didukung oleh Rini, dkk (2015), Plorensia A.P. dan Hardiningsih (2015) serta Utari dan Rohman (2015). Sedangkan Octaviana dan Rohman (2014) serta Zeng (2012) menyatakan agresivitas pajak berpengaruh negatif terhadap corporate social responsibility. Kuriah (2016) dan Sari (2016) juga menyatakan bahwa agresivitas pajak dan CSR memiliki hubungan negatif dan signifikan. Berdasarkan uraian tersebut, maka 
Ida Ayu Intan Suryadewi dan Ni Ketut Rasmini.Pengaruh...

rumusan hipotesis yang dapat diajukan dalam penelitian ini adalah sebagai berikut.

$\mathrm{H}_{1}$ : Agresivitas pajak berpengaruh pada corporate social responsibility.

Ukuran perusahaan merupakan salah satu faktor yang mempengaruhi perusahaan dalam membayar pajak. Kristanto (2013) menyatakan perusahaan yang besar tentunya juga mempunyai pengalaman yang lebih banyak dalam menjalankan kegiatan operasinya, dan memiliki kematangan yang lebih dalam strategi untuk kelangsungan operasinya, termasuk strategi penghematan pajak. Tiaras dan Wijaya (2015) serta Hsieh (2012) mendapatkan hasil bahwa ukuran perusahaan memiliki pengaruh yang signifikan terhadap tingkat agresivitas pajak perusahaan.Kuriah (2016) mendapatkan hasil bahwa ukuran perusahaan memiliki pengaruh terhadap agresivitas pajak artinya besar kecilnya suatu perusahaan akan mempengaruhi tingkat agresivitas pajak di setiap perusahaan. Penelitian terdahulu dilakukan oleh Hartadinata dan Tjaraka (2013) mendapatkan hasil bahwa ukuran perusahaan berpengaruh negatif terhadap agresivitas pajak. Kurniasih dan Sari (2013), serta Rinaldi dan Cheisviyanny (2015) menghasilkan pengaruh negatif antara ukuran perusahaan dengan tax avoidance yang merupakan bagian dari tindakan agresivitas pajak. Berdasarkan uraian tersebut, maka rumusan hipotesis yang dapat diajukan dalam penelitian ini adalah sebagai berikut.

$\mathrm{H}_{2}$ : Ukuran perusahaan memoderasi pengaruh agresivitas pajak pada corporate social responsibility. 


\section{METODE PENELITIAN}

Pendekatan yang digunakan dalam penelitian ini adalah pendekatan kuantitatif yang berbentuk asosiatif dengan tipe kausalitas. Hal ini dikarenakan penelitian ini menjelaskan hubungan dari agresivitas pajak pada corporate social responsibility dengan ukuran perusahaan sebagai pemoderasi (Sugiyono, 2016:11).Penelitian ini dilakukan pada perusahaan sektor pertambangan yang terdaftar di Bursa Efek Indonesia (BEI) pada tahun 2014-2016. Obyek dalam penelitian ini adalah agresivitas pajak dari GAAP Effective Tax Rate (ETR), ukuran perusahaan dari logaritma natural of total assets, danpengungkapan corporate social responsibility dari CSRI pada laporan keuangan dan laporan tahunan perusahaan pertambangan yang terdaftar di BEI.

Corporate social responsibility adalah tanggung jawab moral suatu perusahaan kepada para stakeholdernya, terutama komunitas atau masyarakat di sekitar wilayah kerja dan operasinya. Dalam penelitian ini pengungkapan Corporate Social Responsibility (CSR) diukur dengan menggunakan acuan pada indikator Global Reporting Initiative (GRI) Generation 4 (G4) yang berjumlah 91 item. Global Reporting Initiative (GRI)G4 merupakan generasi terbaru pada tahun 2013. Indeks luas pengungkapan CSR (CSRI) dirumuskan sebagai berikut.

$$
\mathrm{CSRI}=\frac{\sum \mathbf{X} \mathbf{i j}}{\mathbf{n j}}
$$

Keterangan:

CSRI : Pengungkapan tanggung jawab sosial perusahaan

$\sum \mathrm{X}_{\mathrm{ij}}$ : Dummy variabel: $1=$ jika item $\mathrm{i}$ diungkapkan, $0=$ jika item $\mathrm{i}$ tidak diungkapkan

$\mathrm{N}_{\mathrm{j}} \quad$ : Jumlah item untuk perusahaan $\mathrm{j}, \mathrm{n}_{\mathrm{j}} \leq 91$ 
Ida Ayu Intan Suryadewi dan Ni Ketut Rasmini.Pengaruh...

Semua usaha yang dilakukan oleh manajemen untuk mengurangi jumlah beban pajak darijumlah seharusnya yang dibayar oleh perusahaan dapat didefinisikan sebagai agresivitas pajak (Lanis dan Richardson, 2012). Dalam penelitian ini agresivitas pajak diproyeksikan dengan Generally Accepted Accounting PrinciplesEffective Tax Rate (GAAP ETR).GAAP ETR dihitung dengan menggunakan rumus sebagai berikut.

$$
\text { GAAP ETR }=\frac{\text { TE }}{\text { PI }}
$$

Keterangan:

GAAP ETR : GAAP Effective Tax Rate

TE $\quad:$ Tax Expense $=$ Total beban pajak penghasilan

PI : Pretax Income = Laba sebelum pajak penghasilan

Ukuran perusahaan merupakan suatu pengukuran yang dikelompokkan berdasarkan besar kecilnya perusahaan dan dapat menggambarkan aktivitas serta pendapatan perusahaan (Nugraha dan Meiranto, 2015). Dalam penelitian ini ukuran perusahaan diproksikan dengan total aktiva perusahaan yang diperoleh dari neraca perusahaan yang diukur menggunakan logaritma natural of total assets, yang rumusnya sebagai berikut.

$$
\text { Size }=\text { Ln (Total Assets })
$$

Dalam penelitian ini yang menjadi populasi adalah seluruh perusahaan pertambangan yang terdaftar di Bursa Efek Indonesia (BEI) pada tahun 2014 hingga 2016.Metode penentuan sampel yang digunakan dalam penelitian ini adalah pendekatan nonprobability sampling dengan teknik purposive sampling, dengan menggunakan kriteria sebagai berikut:1) Perusahaan pertambangan yang terdaftar di Bursa Efek Indonesia (BEI) dari tahun 2014-2016.2)Perusahaanyang 
menerbitkan laporan keuangan tahunan yang telah diaudit dan terpublikasi dengan lengkap dari tahun 2014-2016.3) Perusahaan tidak mengalami kerugian selama tahun penelitian dari 2014-2016. Hal ini karena akan menyebabkan nilai Effective Tax Rate mejadi negatif sehingga akan menyulitkan perhitungan. 4) Perusahaan mengungkapkan CSR disclosure dalam laporan tahunan.

Berdasarkan kriteria tersebut jumlah observasi yang diperoleh untuk penelitian adalah sebanyak 14perusahaan dengan total 42 observasian. Pada penelitian ini mempergunakan metode pengumpulan data observasi nonpartisipan. Dilakukan Uji Statistik Deskriptif, Uji Asumsi Klasik hingga Uji Moderated Regression Analysis (MRA) yang menghasilkan persamaan sebagai berikut.

$\mathrm{Y}=\alpha+\beta_{1} \mathrm{X}_{1}+\beta_{2} \mathrm{X}_{2}+\beta_{3} \mathrm{X}_{1} \mathrm{X}_{2}+e$

Keterangan:

$\mathrm{Y}=$ Corporate Social Responsibility

a $\quad=$ Konstanta

$\mathrm{b}_{1}, \mathrm{~b}_{2}, \mathrm{~b}_{3} \quad=$ Koefisien regresi

$\mathrm{X}_{1} \quad=$ Agresivitas pajak

$\mathrm{X}_{2} \quad=$ Ukuran perusahaan

$\mathrm{X}_{1} \mathrm{X}_{2}=$ Interaksi antara agresivitas pajak dengan ukuran perusahaan

$e \quad=$ error term (residual)

\section{HASIL DAN PEMBAHASAN}

Setelah dilakukan observasi penelitian, perusahaan yang dapat dijadikan sampel sebanyak 14 perusahaan dengan total 42 sampel amatan yang ditunjukkan dengan proses seleksi sebagai berikut. 
Tabel 1.

Hasil Seleksi Pemilihan Sampel

\begin{tabular}{ccc}
\hline No. & \multicolumn{1}{c}{ Kriteria } & Jumlah \\
\hline 1 & Perusahaan pertambangan yang terdaftar di BEI dari tahun 2014-2016 & 42 \\
2 & $\begin{array}{l}\text { Perusahaan yang tidak menerbitkan laporan keuangan tahunannya berturut- } \\
\text { turut dari tahun 2014-2016 dan tidak terpublikasi secara lengkap }\end{array}$ & $(11)$ \\
3 & $\begin{array}{l}\text { Perusahaan yang mengalami kerugian selama tahun penelitian dari 2014- } \\
\text { 2016 }\end{array}$ & $(17)$ \\
& Sampel yang tidak melaporkan CSR disclosure selama tahun 2014-2016
\end{tabular}

Sumber: Data sekunder diolah, 2017

Statistik deskriptif digunakan untuk mengetahui jumlah sampel, nilai minimum, nilai maksimum, nilai rata-rata, dan standar deviasi dari masing-masing variabel.

Tabel 2.

Statistik Deskripstif Variabel-Variabel Penelitian

\begin{tabular}{cccccc}
\hline Variabel & N & Minimum & Maksimum & Rata-rata & $\begin{array}{c}\text { Deviasi } \\
\text { Standar }\end{array}$ \\
\hline $\begin{array}{c}\text { Corporate Social } \\
\text { Responsibility }(\mathrm{Y})\end{array}$ & 42 & 0,06 & 0,63 & 0,30 & 0,12 \\
Agresivitas Pajak $\left(\mathrm{X}_{1}\right)$ & 42 & 0,21 & 0,98 & 0,38 & 0,18 \\
Ukuran Perusahaan $\left(\mathrm{X}_{2}\right)$ & 42 & 15,25 & 29,83 & 24,97 & 5,10 \\
Interaksi $\left(\mathrm{X}_{1} \mathrm{X}_{2}\right)$ & 42 & 3,61 & 28,72 & 9,77 & 5,66 \\
\hline Sumber: Data diolah, 2017 & & & & &
\end{tabular}

Nilai minimum variabel CSR sebesar 0,06 dan nilai maksimum sebesar 0,63. Variabel CSR yang merupakan pengungkapan tanggung jawab sosial yang diukur dengan 91 item memiliki nilai rata-rata sebesar 0,30. Hal tersebut menunjukkan rata-rata perusahaan sampel telah mengungkapkan sebesar 30\% dari 91 pengungkapan tanggung jawab sosial. Nilai standar deviasi variabel CSR 
sebesar 0,12 . Hal ini berarti nilai ini lebih rendah dibandingkan dengan nilai ratarata, yang artinya sebaran data corporate social responsibility sudah merata.

Nilai minimum GAAP ETR sebesar 0,21 dengan nilai maksimum sebesar 0,98. Sedangkan nilai rata-rata sebesar 0,38 memiliki arti bahwa perusahaan melakukan agresivitas pajak sebesar 38\% dari laba sebelum pajak yang diperoleh dalam satu periode, serta standar deviasi sebesar 0,18 yang lebih kecil dari nilai rata-rata yang berarti sebaran data agresivitas pajak sudah merata. Nilai minimum variabel ukuran perusahaan sebesar 15,25 dengan nilai maksimum sebesar 29,83. Sedangkan nilai rata-rata sebesar 24,97 dengan standar deviasi sebesar 5,10 yang lebih kecil dari nilai rata-rata, yang berarti sebaran data ukuran perusahaan sudah merata.

Nilai minimum variabel interaksi antara agresivitas pajak dengan ukuran perusahaan $\left(\mathrm{X}_{1} \mathrm{X}_{2}\right)$ sebesar 3,61 dan nilai maksimum sebesar 28,72. Nilai rata-rata sebesar 9,77 dengan standar deviasi sebesar 5,66 yang lebih kecil dari pada nilai rata-rata artinya sebaran data ukuran perusahaan yang berinteraksi dengan agresivitas pajak sudah merata. Selanjutnya dilakukan uji asumsi klasik yang meliputi uji normalitas, uji autokorelasi, uji multikolinearitas dan uji heteroskedastisitas untuk mengetahui apakah data dalam penelitian yang dilakukan telah lolos dari asumsi klasik. Nilai Asymp. Sig. (2-tailed) yaitu 0,200 lebih besar dari tingkat signifikansi 0,05, yang berarti data yang digunakan pada penelitian ini telah berdistribusi normal.

Uji selanjutnya yaitu uji multikolinearitas. Uji multikolinearitas bertujuan untuk menguji apakah model regresi ditemukan adanya korelasi antara variabel 
Ida Ayu Intan Suryadewi dan Ni Ketut Rasmini.Pengaruh...

bebas. Hasil uji ini dapat dilihat bahwa nilai tolerance pada masing-masing variabel lebih besar dari 0,1 , demikian pula dengan nilai VIF masing-masing variabel yang lebih kecil dari 10. Hal ini berarti persamaan Moderated Regression Analysis (MRA) dengan variabel terikat corporate social responsibility tidak terdapat masalah multikolinearitas

Berdasarkan hasil uji autokorelasi, menunjukkan bahwa nilai uji Durbin Watson sebesar 1,942. Nilai dU untuk jumlah sampel 42 dengan 3 variabel bebas (k) serta level of significant 5\% (0,05) adalah 1,6617. Maka nilai 4-dU adalah 2,3383, sehingga hasil uji autokorelasinya adalah $\mathrm{dU}<\mathrm{d}<(4-\mathrm{dU})$, yaitu $1,6617<$ $1,942<2,3383$. Hal ini berarti koefisien regresi bebas dari gangguan autokorelasi.

Uji asumsi klasik yang digunakan selanjutnya adalah uji heteroskedastisitas bertujuan menguji apakah terjadi ketidaksamaan variance dalam model regresidari residual satu pengamatan ke pengamatan yang lain. Berdasarkan hasil uji heteroskedastisitas,menunjukkan bahwa nilai signifikansi untuk variabel agresivitas pajak $\left(\mathrm{X}_{1}\right)$ sebesar 0,911, variabel ukuran perusahaan $\left(\mathrm{X}_{2}\right)$ sebesar 0,543 serta variabel interaksi $\left(\mathrm{X}_{1} \mathrm{X}_{2}\right)$ sebesar 0,857 . Hal ini berarti nilai signifikansi masing-masing variabel lebih besar dari 0,05 sehingga dapat disimpulkan bahwa model regresi bebas dari gejala heteroskedastisitas.

Uji Moderated Regression Analysis (MRA) merupakan suatu uji yang dilakukan untuk mengetahui apakah variabel ukuran perusahaan mampu memengaruhi hubungan agresivitas pajak dan corporate social responsibility. 
Tabel 3.

Rekapitulasi Hasil Hasil Uji Moderated Regression Analysis

\begin{tabular}{|c|c|c|c|c|c|c|}
\hline \multirow{2}{*}{\multicolumn{2}{|c|}{ Model }} & \multicolumn{2}{|c|}{$\begin{array}{c}\text { Unstandardized } \\
\text { Coefficients }\end{array}$} & \multirow{2}{*}{$\begin{array}{c}\text { Standardized } \\
\text { Coefficients }\end{array}$} & \multirow{2}{*}{$\mathrm{t}$} & \multirow{2}{*}{ Sig. } \\
\hline & & B & Std. Error & & & \\
\hline \multirow{4}{*}{1} & (Constant) & 0,137 & 0,246 & & 0,558 & 0,580 \\
\hline & $\mathrm{X} 1$ & 1,948 & 0,808 & 2,781 & 2,410 & 0,021 \\
\hline & $\mathrm{X} 2$ & 0,002 & 0,009 & 0,100 & 0,272 & 0,787 \\
\hline & $\mathrm{X} 1 \mathrm{X} 2$ & $-0,066$ & 0,029 & $-3,024$ & $-2,304$ & 0,027 \\
\hline \multicolumn{2}{|c|}{ Adjusted R Square } & \multicolumn{5}{|c|}{0,475} \\
\hline \multicolumn{2}{|c|}{$F$} & \multicolumn{5}{|c|}{13,344} \\
\hline \multicolumn{2}{|c|}{ F Sig. } & \multicolumn{5}{|c|}{0,000} \\
\hline
\end{tabular}

Sumber: Data diolah, 2017

Persamaan regresi yang dihasilkan melalui Moderated Regression Analysis adalah sebagai berikut:

$\mathrm{Y}=0,137+1,948 \mathrm{X}_{1}+0,002 \mathrm{X}_{2}-0,066 \mathrm{X}_{1} \mathrm{X}_{2}+e$

Nilai konstanta $(\alpha)$ sebesar 0,137 berarti jika semua variabel independen konstan, maka variabel dependen yaitu corporate social responsibility (Y) yang diproksikan dengan CSRI meningkat sebesar 0,137 . Nilai koefisien regresi $\left(\beta_{1}\right)$ dari agresivitas pajak $\left(\mathrm{X}_{1}\right)$ yaitu 1,948 memiliki arti bahwa ketika nilai agresivitas pajak yang diproksikan dengan GAAP Effective Tax Rate (ETR) meningkat 1 satuan, maka corporate social responsibility $(\mathrm{Y})$ yang diproksikan dengan CSRI meningkat sebesar 1,948 satuan, dengan asumsi variabel independen lainnya konstan. Nilai koefisien regresi $\left(\beta_{2}\right)$ dari ukuran perusahaan $\left(\mathrm{X}_{2}\right)$ yaitu sebesar 0,002 berarti jika ukuran perusahaan meningkat 1 satuan, maka corporate social responsibility (Y) meningkat sebesar 0,002 satuan, dengan asumsi variabel lainnya konstan.koefisien regresi interaksi $\left(\beta_{3}\right)$ dari agresivitas pajak dan ukuran perusahaan $\left(\mathrm{X}_{1} \mathrm{X}_{2}\right)$ yaitu sebesar $-0,066$ memiliki arti bahwa ketika nilai interaksi 
Ida Ayu Intan Suryadewi dan Ni Ketut Rasmini.Pengaruh...

meningkat sebesar 1 satuan, maka corporate social responsibility menurun sebesar 0,066 satuan dengan asumsi variabel independen lainnya konstan.

Adapun nilai dari adjusted $R$ square pada penelitian ini telah disajikan pada Tabel 4. menunjukkan nilai koefisien determinasi sebesar 0,475 yang berarti 47,5\% variasi corporate social responsibility dapat dijelaskan oleh variasi dari agresivitas pajak dan ukuran perusahaan, sedangkan sebesar 52,5\% dapat dijelaskan oleh variabel-variabel lain di luar model penelitian.

Berdasarkan hasil uji kelayakan model pada Tabel 4 di atas, dapat dilihat nilai $\mathrm{F}$ hitung sebesar 13,344 dengan tingkat signifikansi sebesar 0,000 $<0,05$. Hasil tersebut menunjukkan bahwa agresivitas pajak dan interaksi agresivitas pajak dengan ukuran perusahaan secara signifikan mampu mempengaruhi corporate social responsibility. Berdasarkan hal tersebut maka dapat disimpulkan bahwa model penelitian ini dapat dikatakan layak untuk diteliti dan dapat dilanjutkan dengan pembuktian hipotesis.

Uji statistik t dilakukan untuk mengetahui seberapa besar pengaruh variabel independen terhadap variabel dependen secara parsial. Uji statistik t dilakukan dengan membandingkan hasil nilai signifikansi dengan $\alpha=0,05$. Berdasarkan Tabel 4. hasil uji statistik t menunjukkan bahwa variabel agresivitas pajak $\left(\mathrm{X}_{1}\right)$ yang diproksikan dengan GAAP ETR memiliki nilai signifikansi sebesar 0,021 < 0,05. Berdasarkan hal tersebut maka hipotesis pertama $\left(\mathrm{H}_{1}\right)$ diterima. Arah koefisien regresi yang positif menunjukkan GAAP ETR sebagai proksi agresivitas pajak berpengaruh positif pada corporate social responsibility. Artinya, jika tingkat agresivitas pajak tinggi maka pengungkapan corporate social 
responsibility meningkat atau sebaliknya jika tingkat agresivitas pajak rendah maka pengungkapan corporate social responsibility menurun. Berdasarkan hasil uji statistik deskriptif menunjukkan nilai rata-rata agresivitas pajak yang diproksikan dengan GAAP ETR dan corporate social responsibility masingmasing memiliki nilai rata-rata yang rendah yaitu 0,38 dan 0,30 . Berdasarkan hal tersebut dapat disimpulkan hasil penelitian ini menunjukkan agresivitas pajak berpengaruh positif pada pengungkapan corporate social responsibility. Artinya, semakin rendah tingkat agresivitas pajak maka pengungkapan corporate social responsibility akan menurun.

Hasil penelitian ini sejalan dengan Lanis dan Richardson (2013), Rini, dkk (2015), Plorensia A.P. dan Hardiningsih (2015) serta Utari dan Rohman (2015) yang menyatakan agresivitas pajak berpengaruh positif terhadap corporate social responsibility. Hal ini menunjukkan bahwa suatu perusahaan yang memiliki tingkat agresivitas pajak rendah akan cenderung mengungkapkan informasi CSR nya lebih sedikit atau sebaliknya suatu perusahaan yang memiliki tingkat agresivitas pajak tinggi akan cenderung mengungkapkan informasi CSR lebih besar untuk mendapatkan legitimasi dari masyarakat dan patuh dalam melaksanakan kebijakan pemerintah di bidang sosial dan ekonomi. Tindakan agresivitas pajak merupakan tindakan yang tidak sesuai dengan harapan masyarakat dan memiliki dampak negatif terhadap masyarakat. Pandangan negatif masyarakat terhadap perusahaan, berpotensi terhadap hilangnya legitimasi perusahaan yang akan mengancam kelangsungan hidup perusahaan. Hal ini mendorong perusahaan untuk mengungkapkan tanggung jawab sosialnya lebih 
Ida Ayu Intan Suryadewi dan Ni Ketut Rasmini.Pengaruh...

luas sehingga dapat mengurangi dampak negatif yang ditimbulkan dari kegiatan agresivitas pajak. Hasil penelitian ini mendukung teori legitimasi yang menyatakan bahwa suatu perusahaan yang terbukti melakukan tindakan agresivitas pajak akan bertindak sesuai dengan teori legitimasi yaitu dengan cara melakukan pengungkapan informasi CSR tambahan (Lanis dan Richardson (2013) dengan tujuan mengubah persepsi masyarakat dan mendapat legitimasi dari masyarakat. Penelitian ini juga sesuai dengan teori stakeholder, dalam menjalankan operasinya setiap perusahaan tidak lepas dari dukungan para stakeholdernya. Tindakan agresivitas pajak tentu tidak sesuai dengan harapan stakeholder, maka untuk menutupi hal tersebut suatu perusahaan akan melakukan kegiatan CSR yang tinggi, sehingga dapat mendorong peningkatan reputasi dalam pengoperasian perusahaan. Hal tersebut akan berdampak pada terciptanya kepercayaan dari berbagai pihak dan meningkatkan citra perusahaan dimata para stakeholder.

Kemudian uji hipotesis kedua diperoleh nilai signifikansi uji t berdasarkan Tabel 4. variabel interaksi agresivitas pajak dengan ukuran perusahaan memiliki nilai signifikansi sebesar $0,027<0,05$. Berdasarkan hal tersebut maka hipotesis kedua $\left(\mathrm{H}_{2}\right)$ diterima. Hasil pengujian tersebut menyatakan bahwa ukuran perusahaan mampu memoderasi pengaruh agresivitas pajak pada corporate social responsibility.Koefisien regresi interaksi agresivitas pajak dengan ukuran perusahaan $\left(\mathrm{X}_{1} \mathrm{X}_{2}\right)$ sebesar $-2,304$ menunjukkan bahwa ukuran perusahaan memperlemah pengaruh agresivitas pajak pada corporate social responsibility. Hasil ini menunjukan tingkat agresivitas pajak akan menurun dengan semakin 
besarnya ukuran perusahaan yang menyebabkan pengungkapan tanggung jawab sosial perusahaan akan meningkat.Semakin besar ukuran perusahaan maka pemerintah cenderung akan lebih memonitoring entitas tersebut sehingga entitas menjadi lebih patuh dalam memenuhi kewajiban perpajakannya (Kurniasih dan Sari, 2013). Sesuai dengan teori biaya politik (political cost theory) yang menyatakanperusahaan tidak selalu dapat menggunakan power yang dimilikinya untuk melakukan perencanaan pajak karena adanya batasan berupa kemungkinan menjadi sorotan dan sasaran dari keputusan regulator (Watts dan Zimmerman, 1986).

Tindakan agresivitas pajak yang dilakukan perusahaan akan berkurang untuk dapat mempertahankan citra positif perusahaan dimata stakeholdernya dan tetap mendapat kepercayaan dari berbagai pihak. Hasil penelitian ini sejalan dengan Haryanto (2015) yang menyatakan ukuran perusahaan berpengaruh positif terhadap pengungkapan corporate social responsibility. Artinya, semakin besar suatu ukuran perusahaan akan mengungkapkan informasi yang lebih banyak daripada perusahaan kecil yang diukur dengan besar kecilnya total asset yang dimiliki. Kurniasih dan Sari (2013), serta Rinaldi dan Cheisviyanny (2015) menghasilkan pengaruh negatif antara ukuran perusahaan dengan tax avoidance yang merupakan bagian dari tindakan agresivitas pajak. Penelitian tersebut menyatakan bahwa semakin besar ukuran perusahaan maka pemerintah cenderung akan lebih memonitoring entitas tersebut sehingga entitas menjadi lebih patuh dalam memenuhi kewajiban perpajakannya dan cenderung akan lebih memperhitungkan risiko yang akan ditimbulkan dari aktivitas agresivitas pajak 
Ida Ayu Intan Suryadewi dan Ni Ketut Rasmini.Pengaruh...

perusahaannya untuk mempertahankan citra perusahaan. Hasil penelitian ini juga mendukung teori stakeholder, dimana dalam menjalankan kegiatan operasinya perusahaan tidak terlepas dari dukungan para stakeholdernya. Dengan demikian, perusahaan besar cenderung akan lebih patuh terhadap peraturan pemerintah dan berusaha untuk meningkatkan tanggung jawab sosial perusahaannya dengan tujuan mempertahankan citra positif perusahaan dimata para stakeholder yang akan berdampak pada keberlangsungan hidup perusahaan.

Implikasi penelitian ini dibagi atas dua jenis; 1) Implikasi teoritis penelitian ini menghasilkan simpulan mengenai bagaimana pengaruh agresivitas pajak pada corporate social responsibility dengan ukuran perusahaansebagai variabel moderasi. Hasil dari penelitian ini dapat memberikan wawasan terkait corporate social responsibility, agresivitas pajak, serta ukuran perusahaan. Penelitian ini didukung oleh teori legitimasi yang menyatakan setiap perusahaan yang terbukti melakukan tindakan agresivitas pajak akan bertindak sesuai dengan teori legitimasi yaitu dengan cara melakukan pengungkapan informasi CSR tambahan (Lanis dan Richardson (2013) dengan tujuan mengubah persepsi masyarakat dan mendapat legitimasi dari masyarakat. Penelitian ini juga didukung oleh teori stakeholder, dimana perusahaan dalam menjalankan kegiatan operasinya tidak dapat terlepas dari dukungan para stakeholdernya. Perusahaan akan cenderung menghindari tindakan agresivitas pajak yang dapat merusak citra perusahaan dimata para stakeholdernya. Selain itu menurut teori biaya politik (political cost theory)perusahaan besar tidak selalu dapat menggunakan power yang dimilikinya untuk melakukan perencanaan pajak karena adanya batasan berupa kemungkinan 
menjadi sorotan dan sasaran dari keputusan regulator. Sehingga perusahaan besar akan lebih patuh terhadap peraturan perpajakan dengan meminimalkan tindakan agresivitas pajaknya dan meningkatkan tanggung jawab sosial perusahaan dengan tujuan mendapatkan citra positif dari berbagai pihak. 2) Implikasi praktis hasil penelitian ini diharapkan dapat memberikan kontribusi positif bagi semua pihak khususnya pihak investor dan perusahaan. Bagi pihak perusahaan agar dapat meminimalkan tindakan agresivitas pajak karena risiko yang ditimbulkan dapat mengurangi citra perusahaan. Perusahaan juga diharapkan untuk dapat meningkatkan tanggung jawab sosial perusahaannya karena hal tersebut dapat mempertahankan kepercayaan stakeholder dan membangun citra yang positif bagi perusahaan. Dengan demikian para investor akan termotivasi untuk menanamkan modalnya diperusahaan tersebut. Selanjutnya, bagi investor dalam melakukan investasi agar dapat memperhatikan tarif pajak efektif dan total aktiva yang menggambarkan ukuran dari suatu perusahaan, serta memperhatikan tanggung jawab sosial perusahaan tersebut karena hal-hal tersebut dapat mempengaruhi citra perusahaan.

\section{SIMPULAN}

Kesimpulan dari penelitian ini yaitu: 1) Agresivitas pajak yang diproksikan dengan GAAP Effective Tax Rate (ETR) berpengaruh secara positif pada pengungkapan corporate social responsibility. Artinya, jika agresivitas pajak tinggi maka pengungkapan corporate social responsibility akan meningkat atau sebaliknya; 2)Ukuran perusahan mampu memoderasi pengaruh agresivitas pajak pada pengungkapan corporate social responsibility. Namun, ukuran perusahaan 
Ida Ayu Intan Suryadewi dan Ni Ketut Rasmini.Pengaruh...

memperlemah pengaruh agresivitas pajak pada pengungkapan corporate social responsibility. Artinya, jika terjadi peningkatan ukuran perusahaan maka akan memperlemah pengaruh agresivitas pajak pada pengungkapan corporate social responsibility

Adapun beberapa hal yang dapat disarankan sesuai dengan hasil pembahasan hingga kesimpulan yang disajikan pada penelitian ini meliputi: 1) Bagi perusahaan yang terdaftar dalam sektor pertambangan di Bursa Efek Indonesia sebaiknya meminimalisir tindakan agresivitas pajak dan lebih meningkatkan tanggung jawab sosial perusahaan secara konsisten dan berkesinambungan, sehingga dengan begitu dapat mempertahankan citra positif dari perusahaan dimata publik. 2) Bagipara investor diharapkan mampu menyimak laporan keuangan tahunan yang dipublikasikan di Bursa Efek Indonesia agar mengetahui indikasi terjadinya tindakan agresivitas pajak serta seberapa tinggi pengungkapan tanggung jawab sosial perusahaan dan mampu mengetahui ukuran perusahaan untuk pertimbangan dalam melakukan investasi. 3) Bagi peneliti selanjutnya diharapkan menggunakan proksi pengukuran agresivitas pajak yang berbeda selain GAAP ETR, seperti Current ETR, Cash ETR, Book Tax Defference (BTD). Selain itu, bagi penelitian selanjutnya agar dapat mengkaji dan menyempurnakan variabel lain dari model penelitian ini seperti leverage, dan profitabilitas dan diharapkan mampu memperluas objek penelitian baik dari segi bidang usaha maupun periode penelitian. 


\section{REFERENSI}

Andhari, Putu Ayu Seri., dan Sukartha, I Made. 2017. Pengaruh Pengungkapan Corporate Social Responsibility, Profitabilitas, Inventory Intensity,Capital Intensity,dan Leverage pada Agresivitas Pajak. E-Jurnal Akuntansi Universitas Udayana, 18(3), hal:2115-2142.

Aryudanto, Indra. 2016. Analisis Pengaruh Agresivitas PajakTerhadap Pengungkapan Corporate Social Responsibility (Studi Empiris Pada Perusahaan Non Keuangan yang Terdaftar di BEI pada tahun 2014). Skripsi.Fakultas Ekonomika dan Bisnis Universitas Diponegoro.

Balakrishnan, K., Blouin, J., \& Guay, W. (2012). Does Tax Aggressiveness Reduce Corporate Transparency?. Social Science Research Network, 23, 4668.

Chen, dkk. 2010. Are Family Firms More Tax Aggressive Than Non-family Firms. Journal of Financial Economics, 95, pp: 41-61.

Dharma, I Made Surya., dan Ardiana, Putu Agus. 2016. Pengaruh Leverage, Intensitas Aset Tetap, Ukuran Perusahaan, dan Koneksi Politik terhadap Tax Avoidance. E-Jurnal Akuntansi Universitas Udayana, 15(1), hal: 584-613.

Donaldson, Thomas., dan Preston, Lee E. 1995. The Stakeholder Theory of the Corporation: Concepts, Evidence, and Implications. The Academy of Management Review, 20(1), pp: 65-91.

Fontaine, Michael. 2013. Corporate Social Responsibility and Sustainability: The New Bottom Line. International Journal of Business and Social, 4 (4), pp: 110-119.

Frank, M.M., Lynch, L.J., \& Rego, S.O. 2009. Tax Reporting Aggressiveness and Its Relation to Aggressive Financial Reporting.The Accounting Review, 84(2), pp: 467-496.

Hanlon, Michelle., \& Heitzman, Shane. (2010). A review of tax research. Journal of Accounting and Economics, 50(40), pp: 127 - 178.

Harari, M., O. Sitbon, and R. Donyets. 2012. "The Missing Billions:Aggressive Tax Planning and Corporate Social Responsibility in Israel".

Hartadinata, Okta S., dan Tjaraka, Heru. 2013. Analisis Pengaruh Kepemilikan Manajerial, Kebijakan Hutang, dan Ukuran Perusahaan Terhadap Tax Aggressiveness pada Perusahaan Manufaktur di Bursa Efek Indonesia Periode Tahun 2008-2010. Jurnal Ekonomi dan Bisnis, Tahun XXIII, No. 3.

Haryanto, Adetya Agung Kusumo Bawono.2015. Pengaruh Ukuran Perusahaan, Leverage, Profitabilitas, Cakupan Operasional Perusahaan, dan Sertifikasi ISO 14001 terhadap Pengungkapan Corporate Social Responsibility. Diponogoro Journal of Accounting, 4(3), ha: 1-12. 
Hidayat, Muhammad. 2017. Faktor-Faktor yang Mempengaruhi Pengungkapan Sukarela pada Laporan Tahunan Sektor Perbankan di Bursa Efek Indonesia. Jurnal Dimensi, 6(1) h:151-172

Hsieh, Yao-Chih. (2012) "New evidence on determinants of corporate effective tax rates". African Journal of Business Management. 6(3). hal 1177-1180

Kamil, Ahmad., dan Antonius Herusetya. 2012. Pengaruh Karakteristik Perusahaan Terhadap Luas Pengungkapan Kegiatan Corporate Social Responsibility. Media Riset Akuntansi, 2(1), h: 1-17.

Kotler, P. \& Lee, N. (2005). Corporate social responsibility: Doing the most good for your company and your cause. New Jersey: John Wiley \& Son, Inc.

Kuriah, Hanik Laikatul., dan Asyik, Nur Fadjrih. 2016. Pengaruh Karakteristik Perusahaan dan Corporate Social Responsibility terhadap Agresivitas Pajak. Jurnal riset dan Ilmu Akuntansi, 5(3).

Kurniasih, Tommy dan Sari, Maria M. Ratna. 2013. Pengaruh Return On Assets, Leverage, Corporate Governance, Ukuran Perusahaan dan Kompensasi Rugi Fiskal pada Tax Avoidance. Buletin Studi Ekonomi, (18), pp: 58-66.

Laguir, I., Stagliano, R., dan Elbaz, J., 2015. Does Corporate Social Responsibility Affect Corporate Tax Aggressiveness?. Journal of Cleaner Production. Pp: 662-675.

Lanis, R. And G. Richardson. 2012. Corporate Social Responsibility and Tax Aggressiveness: An Empirical Analysis. J.Account. Public Policy, pp.86108.

Lanis, R., and G. Richardson. 2013. Corporate Social Responsibility and Tax Aggressiveness: a test of legitimacy theory. Accounting Auditing and Accountability Journal, 26 (1), pp: 75-100.

Lindawati, A.S.L., dan Puspita, M.E. 2015. Corporate Social Responsibility: Implikasi Stakeholder dan Legitimacy GAP dalam Peningkatan Kinerja Perusahaan. Jurnal Akuntansi Multiparadigma JAMAL, 6 (1), pp: 1-174.

Lovink Angel Dwikarina, Etna Afri Yuyetta. 2013. Analisis Faktor-Faktor yang Mempengaruhi Corporate Social Responsibility, 2(2).

Maharani, I Gusti Ayu Cahya dan Ketut Alit Suardana. 2014. Pengaruh Corporate Governance, Profitabilitas, dan Karakter Eksekutif Pada Tax Avoidance Perusahaan Manufaktur. Journal. E-jurnal Akuntansi Universitas Udayana, 9(2), pp: 525-539.

Nanda, Nila., dan A. Darono. 2015. Pengaruh Agrsivitas Pajak Terhadap Pengungkapan Corporate Social Responsibility. Jurnal Akuntansi Bisnis, 5(2): h: 1-9.

Nugraha, Novia Bani., dan Meiranto, Wahyu. 2015. Pengaruh Corporate Social responsibility, Ukuran Perusahaan, Profitabilitas, Leverage dan Capital 
Intensity terhadap Agresivitas Pajak. Diponegoro Journal of Accounting, 4(4): h:1-14.

Octaviana, N. Elma., dan A. Rohman. 2014. Pengaruh Agresivitas Pajak tehadap Corporate Social Responsibility: Untuk Menguji Teori Legitimasi. Diponegoro Journal of Accounting, 3(2): h:1-12.

O'Donovan. 2000. Environmental Disclosure in the Annual Reports: Extending the Applicability and Predictive Power of Legitimacy Theory.Accounting, Auditing and Accountability Journal, 15 (3), pp: 344-371.

Philip, Kotler., dan Nancy, Kotler. 2005. Corporate Social Responsibility, Doing the Most Good for Your Company and Your Cause. Canada: John Willey \& Sons. Inc.

Rinaldi dan Cheisviyanny, Charoline. 2015. Pengaruh Profitabilitas, Ukuran Perusahaan dan Kompensasi Rugi Fiskal Terhadap Tax Avoidance. Seminar Nasional Ekonomi Manajemen dan Akuntansi (SNEMA) Fakultas Ekonomi Universitas Negeri Padang.

Rini, Diah Mustika, L. Handajani, dan E.E. Sasanti. 2015. “Agresivitas Pajak pada Perusahaan Publik Indonesia yang Melakukan Pengungkapan Corporate Social Responsibility". Jurnal Simposium Nasional Akuntansi XVIII.

Rodriguez, E. F., dan Arias, A. M. 2012. Do Business Characteristics Determine an Effective Tax Rate?. The Chinese Economy. Vol. 45, No. 6.

Sari, Dahlia., dan Tjen, Christine. 2016. Corporate Social Responsibility Disclosure, Environmental Performance, and Tax Aggressiveness. International Research Journal of Bussiness Studies, 9(2), pp:93-104.

Sari, Santi Hersita., dkk. 2012. Faktor-Faktor yang Berpengaruh Terhadap Pengungkapan Tanggung Jawab Sosial Perusahaan. Skripsi. Palembang: Universitas Bina Darma.

Sharma, S., Joity., and Devi. 2009. Corporate Social Responsibility: The Key Role of Human Resource Management. Business Intelligence Journal, 2 (1), pp: 205-213.

Suprimarini, N.P. Deiya., dan Suprasto H., Bambang. 2017. Pengaruh Corporate Social Responsibility, Kualitas Audit, dan Kepemilikan Institusional pada Agresivitas Pajak. E-Jurnal Akuntansi Universitas Udayana, 19(2), h:13491377.

Utari, Intan Ayu., dan Rohman, A. 2015. Pengaruh Agresivitas Pajak terhadap Corporate Social Responsibility: untuk Menguji Teori Legitimasi. Diponegoro Journal of Accounting, 4(1): h:1-13.

Watts,R., dan Zimmerman, J. 1986. Towards a Positive Theory of Accounting. New Jersey: Prentice-Hall. 
Ida Ayu Intan Suryadewi dan Ni Ketut Rasmini.Pengaruh...

Zeng,T. 2012. “Corporate Social Responsibility and Tax Aggressiveness”. Social Science Research Network.

Zulaikha, Danis Ardyansah. 2014. Pengaruh Zise, Leverage, Profitability, Capital Intensity Ratio dan komisaris Independen terhadap Effective Tax Rate (ETR). Diponegoro Journal of Accounting, 3(2), hal: 1-9. 